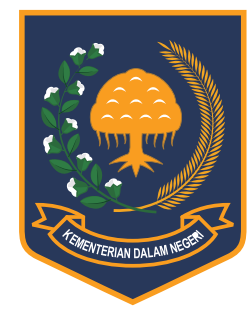

Jurnal Bina Praja 10 (1) (2018): 39-46

Jurnal Bina Praja

e-ISSN: 2503-3360 | p-ISSN: 2085-4323

Accreditation Number

735/AU2/P2MI-LIPI/04/2016

http://jurnal.kemendagri.go.id/index.php/jbp/index

\title{
The Feasibility of the Policy FOR THE USE OF TECHNOLOGY SUMMARY OF E-VOTE RESULT ON THE 2019 ELECTION
}

\author{
Josep Ginting ${ }^{1}$, Hotnier Sipahutar ${ }^{2}$, Abdul Halik ${ }^{3,}{ }^{*}$ \\ ${ }_{1,2,3}$ Research and Development Agency, \\ Ministry of Home Affairs, Republic of Indonesia \\ Jalan Kramat Raya No. 132, Senen, Central Jakarta
}

Received: 13 January 2018; Accepted: 4 April 2018; Published online: 12 May 2018

DOI: $10.21787 / j b p .10 .2018 .39-46$

\begin{abstract}
Problematic manual recapitulation led to the development of the use of e-recapitulation technology. This study aims to determine the feasibility of using e-recapitulation of vote counting in the upcoming 2019 general election. The location of this study was in Pekalongan, Central Java Province (pilot project using e-recapitulation). The method used is the descriptive qualitative method, the sources KPUD officers, Bawaslu officers, the DPRD, and the political unit of the Kesbangpol of Pekalongan. Data collection techniques used were the interview techniques. The technique of data analysis is the inductive basis, i.e., the data collected are discussed, interpreted, and collected in an inductive manner, and draw conclusions from the specific data. Field results show that technology basically e-vote election results recap (in particular_ USSD and DMR) is feasible to be used on the 2019 concurrent election, based on its ability to maintain the integrity of the vote-counting results from the polling stations. Although in the technology itself, the e-recapitulation technology is feasible to be used, it is expected that various problems as identified in this study would occur in the field during the implementation of the technology. Therefore, there needs to be a policy to anticipates the problems that might arise in the use of e-recapitulation technology in the 2019 elections. Such as early communication between the Ministry of Home Affairs and the Central Election Commission to require the use of e-recapitulation in 2019 election, to improve the quality of democracy in Indonesia, as well as to prepare the internet network throughout Indonesia.
\end{abstract}

Keywords: Democracy, Simultaneous Election, E-Recapitulation

\section{INTRODUCTION}

Indonesia is the most advanced developing countries in democracy. Currently, Indonesia embraced direct democracy, whereby the people directly elect the President and the head of the regions. However, the quality of democracy in Indonesia is still far from the goal of democracy for the prosperity and fulfillment of the individual rights of the people (Bachtiar, 2014).

Given a large number of aspects of the general election, this study needs to be focused on a certain aspect. The focus of this strategic assessment is limited on the recapitulation of the vote results in the election. The limitation of this study amongst other things associated with the situation that the recapitulation system in the legislative elections of the sub-district level in 2009 are prone to violations and s not effective. This happens because the recapitulation system reduced the function of PPS in conducting the recapitulation of the vote count in the village level (Jumansyah, 2015). Voice recapitulation is also the most vulnerable stage to manipulation. The most common and prominent form of manipulation at this stage is vote tampering in -both the reduction of votes and the addition of votes-illegally made between candidates from the same political party (Lembaga Penelitian Pendidikan Penerangan Ekonomi dan Sosial (LP3ES), 2014).

Unfortunately, both studies mentioned earlier did not recommend e-recap as a solution to fix the problem, as expressed by Setiawaty \& Vishnu (2017) that electronic recapitulation system (e-recap)

\footnotetext{
* Corresponding Author

Phone : +6281386529490

Email :liknph@yahoo.com
} 
is a strategic step in addressing the question of the problematic vote recapitulation and can also develop the election technology in Indonesia, since the vote result of each Polling Station to can be published faster. It is similar with Anggraini (2014) which stated that from previous experience in the field, the most appropriate technology to improve the quality of Indonesia's vote result was e-recap, for e-recap had many advantages and successfully applied without a significant risk. It was fast and provided an authentic evidence for the vote count at Polling Stations (TPS) level. Thus, the Government and the parliament (DPR) should study and consider the e-recap technology that is being prepared by the Indonesian Election Commission (KPU).

The previous studies, in essence, confirmed that there are many problems regarding the manual recapitulation, it highlights the need to develop the e-recapitulation technology but had not recommended the use of the e-recap on the 2019 simultaneous election.

As such, the "thesis statement" in this study is the urgency and feasibility of E-recap of the calculation result in the vote for the upcoming 2019 simultaneous election (legislation and presidential election). The e-recapitulation technology is an excellent idea and could invite the question/opinion from many angles, it necessitates a "deep analysis ' before it is implemented. This is because there are no laws or regulations requiring the Election Commission (KPU) to recap of the calculation of the votes electronically. The E-Recapitulation that some regions have performed can only be used as a comparison and means to collect authentic evidence of vote results in each TPS.

According to Surbakti, Supriyanto \& Santoso (2013), the Indonesian election systems need E-Recapitulation rather than E-voting, since the Indonesian election system has long recapitulation processes, and prone to manipulation in each of its levels. The long recapitulation process, the longest in the world, is the weakness of our election process. As such, what need to be proposed to the government is e-recapitulation.

In connection with the e-voting technology, the system could be used for the identification of potential voters, registration of potential voters, the voting day and the recapitulation of the vote (Purwati, 2015), and the most appropriate model to be used is a web-based technology (Shalahuddin, 2009), specifically the fingerspot fingerprint sensor (Miharja, Suprapto, Puspitarani, \& Sukenda, 2014). Legally, the use of an electronic system for voting and recapitulation is in accordance with the legal framework for Indonesia (Fuadi, 2015).

E-recapitulation is part of e-voting. Technically, the election vote counting procedure we currently use is too vulnerable to manipulation without a trace. The current vote count procedures do not have adequate validation mechanism that allows organizers to prove the absurdity of a fraudulent claim. Vote counting also involves many paper documents that are easy to imitate (Prasetya, 1997). It is also important to remember that there are a lot of TPS in each sub-district, especially in Java and urban areas, while the time available for recapitulation at the sub-district level is relatively limited. The recapitulation of vote result was conducted in stages from the TPS, Village, Sub-District, District/ City, Province and National levels. It took 3 to 4 weeks to obtain official results of the vote at the National level. Obtaining the national results of each TPS is difficult. In addition, the authentic evidence of the vote result in each of the TPS had not been managed properly. These are some of the problems encountered in the recapitulation of vote result in Indonesian election (Surbakti et al., 2013).

The e-recapitulation systems are assumed to be able to overcome the above problems, because e-recapitulation is using technology to calculate the vote result so that the result instantly would be sent directly to the data center, in this case, the data is sent directly from the TPS to the KPU. With E-Recapitulation, besides a better accuracy, if there is an error, it is possible to trace the error. As for the security system, this system is equipped with some security by the operator (Andrari, 2016).

India started introducing the E-Voting since 1990 by testing in in local elections in several states; the Netherlands began utilizing technology in the voting and counting process in the 1950s; the Philippines have applied the technology and information in the election process, particularly at the polling and vote counting stages; in Brazil, in 2000 Brazil became the only country to have implemented E-Voting in all regions of the country and Brazil has since become a leading country in the use of E-Voting; in the US where in the last election in 2012 there are 3 main types of technology being used, namely; (1) using ballots with electronic counting (2) electronic ballots, and (3) electronic instruments to mark the ballots; in Australia where election machines were tested in Victoria (2006, 2010) and Canberra (2012); and In Germany where Germany first introduced E-Voting in 1998 in its pilot project in the City of Collogne. After the pilot project conducted in the city of Cologne is considered successful, in 1999 the use of E-Voting was used en masse in Cologne City at the time of the election of members of the European Parliament. and an error on the machine or a deliberate election rigging happened (Andrari, 2016).

In relation to the above, BPPT has conducted trials as a proof of concept, on (1) technology USSD, and (2) DMR. The trial was held in Pekalongan City during the legislative elections on April 9, 2014, in 
the 564 TPS without disturbing the ongoing manual electoral process. This trial was conducted jointly by three parties with their respective competencies, BPPT, Pekalongan City and PT Indosat Tbk based on a cooperation agreement between the three parties.

Referring to the above descriptions, the problem to be solved in this study is related to: 1 ) The feasibility of using e-recapitulation technology in the upcoming 2019 election, (2) Identification of the factors expected to affect (support and inhibit) the e-recapitulation technology if it is used in the upcoming 2019 elections and (3) formulate the preparations that need to be performed to overcome the problems that are expected to emerge in the use of recapitulation technology in the upcoming 2019 election.

\section{METHOD}

The location of this study was in Pekalongan City, Central Java Province, as the only region that had ever conducted E-recapitulation of the election result in Indonesia pilot project). The length of this study was 3 (three) months, i.e. March-June 2017. This research used a descriptive method with a qualitative approach.

The data collection method in this study was the interview method. Interview method was used because in this study researchers only ask the competent sources regarding the feasibility or superiority of e-recapitulation technology when compared with the manual recapitulation. The sources were the 2014 legislative election committee in Pekalongan City which was the KPUD officers, the Bawaslu officers, the regional parliament (DPRD) members, and the Political section of Badan Kesbangpol Pekalongan City (8 persons).

Data processing and analysis this study used a qualitative data analysis method, ie data analysis inductively through 4 (four) stages of analysis, namely (1) collection (2) reduction (3) presentation, and (4) drawing the conclusions.

The parameters used to determine whether or not an e-recapitulation system is feasible to be used refers to the purpose of using e-recapitulation technology in the electoral process itself, which are: (1) the speed of delivery of vote recapitulation results from each TPS to the public, (2) the ability to support the public's right to control the vote counting process, (3) the accuracy of the vote result data, (4) the provision of an authentic evidence of the vote count results in level of TPS, (5) the transparency of vote counting process, and (6) the increase of election accountability (Setiawaty \& Vishnu, 2017).

\section{RESULTS AND DISCUSSION}

The e-recap in Pekalongan City was introduced due to the complexity of legislative elections which are generally found to be problematic, such as the process of providing, printing and distributing of ballot papers, including many invalid ballots. In addition, the calculation of the vote results which was performed in stages often results in discrepancies between the manual calculation performed by committee with the calculations made by the witnesses or the public (personal communication, 2017).

The e-recapitulation test was performed by calculating the results in all polling stations (564 TPS) in Pekalongan City. The e-recapitulation test by using the USSD method was conducted West Pekalongan TPS (175 TPS) and in South Pekalongan (111 TPS). The e-recapitulation test by using the DMR method was conducted North Pekalongan TPS (148 TPS) and in East Pekalongan (130 TPS). In total, the USSD method was conducted in 286 TPS and the DMR method in 278 TPS.

\section{A. The Result of the E-Recapitulation Technology Test in Pekalongan City}

The explanation was regarding the architecture of e-Recapitulation technology and various technological alternatives that could be used to support the e-Recapitulation process in the national election, as well as explaining the technological options used in the e-Recapitulation technology test in the Legislative Elections of Pekalongan City, which are the USSD technology and the DMR technology, as well as technology used in the delivery of results (Source: FGD Result in Pekalongan City, 2017). E-recapitulation is a system in which the computation, delivery of calculation and delivery of official election results will be computerized safely, accurately, transparently and quickly.

In general, the description/illustration of e-Recapitulation technology architecture model could be grouped into 5 (five) parts (FGD Result in Pekalongan City, 2017) First, Data Input of the TPS Recapitulation results. Data Input could be conducted by using local application or web-based, by USSD, or by using the electronic scanner, either ICR (Intelligent Character Recognition) or OMR/ DMR (Optical/Digital Mark Reader). The location of the data input might be directly from the TPS by the relevant KPPS or conducted at a designated location such as the Village (PPS), Sub-District (PPK), or at the District/City KPU. the location of the data input would greatly depend on the availability of the data communications network and would significantly affect the speed of e-Recapitulation publication. 
Only data that has been verified correctly can be sent to the KPU Data Center.

Second, Delivery of Recapitulation Result Data of TPS. Delivery of the recapitulation result in the TPS was conducted electronically to KPU data Center, such as through the public internet, or by using a VPN (Virtual Private Network), either VPN Dial VPN Over the Internet. It could also be conducted through mobile telecommunication networks such as SMS, or Fax. The use of communication networks should consider the aspects of network security, Scalability, and the network coverage.

Third, Receipt of TPS Recapitulation Result. Recapitulation data is received by the KPU Data Center and stored in the Submission Server. The submission server used a load balance architecture to optimize its usage. The submission server sent a notification when the data was received correctly. To optimize the data receiving process, a standardization of recapitulation format for all TPS across the country in the XML file is needed. The format of the XML file could be decided by the KPU.

Fourth, The Recapitulation Process. The process of recapitulating the results will be performed on a physically separated server from the Submission Server. In this process, a validation of the data received from the TPS will be conducted. If the submitted data did not pass in any of the validation processes, it will be rejected and stored as an error data and will not be published. The result of the national recapitulation process was stored in Data Warehouse server, separate from the transaction database. Publication of the data would not be conducted by directly accessing the database, but in the form of HTML files, to improve the speed of the data publication and to improve the data security against interference from irresponsible parties through SQL Injection or other means.

Fifth, Publication the Recapitulation Result. The result of the national recapitulation would be published through the KPU Web page, enabling the public to know the vote results in stages down to the TPS level. The published result would not reflect real-time vote result, it would show periodic national recapitulation results. In addition to the data publication through web for the public, the display of data of the vote results for the National Tabulation of Elections (TNP), for mass media (TV), Bawaslu, or other parties was prepared in the form of text file which was sent via data feeder periodically to the server of each institution.

From the results of the e-Recapitulation test in the Legislative Elections of Pekalongan City using the USSD (Unstructured Supplementary Service Data) technology and the DMR (Digital Mark Reader) technology, the USSD technology was able to facilitate the data transmission of the election results for both the Legislative Elections and the Regional Head Election. The use of USSD is recommended with a consideration several things as follows: First, the USSD technology does not require a specific mobile phone, all existing GSM mobile phones can be utilized. For budget efficiency and effectiveness, the KPPS mobile phone devices can be used. The budget required only for the provision of the SIM card.

Second, for security, it is recommended to pair the mobile phone number used with the TPS number. Thus, data from a specific TPS can only be sent by a specific mobile phone with the registered number.

Third, the process of sending data with USSD is very fast and conducted in waves, as such, technically a precaution in the Data Center is needed to avoid a bottleneck in the processing of the data received, to ensure that the results of the vote can be published to the public in a timely manner.

Fourth, for the legal evidence of USSD and as the evidence for the recapitulation official, a photo or scan of Form C1-KPU is sent to the Data Center and used for verification before the results are published to the public (Source: FGD result in Pekalongan City, 2017).

The test results of the use of e-recapitulation technology in the 2014 legislative elections in Pekalongan City with the USSD (Unstructured Supplementary Service Data) technology and the DMR (Digital Mark Reader) technology in 564 TPS is much better than the manual recapitulation of vote results, the e-recapitulation technology was able to provide faster and more accurate data transmission of election results.

Through the use of USSD and DMR technology in the 2014 legislative elections of Pekalongan City the public knows the vote results in the TPS faster, the results was shown directly, supporting the public's right to supervise/control over the vote counting process, minimized errors in vote counting in the TPS, provides authentic evidence because the information was displayed directly at the TPS, more transparent because the results of the vote count were directly informed to the public, as well as the increased accountability of the election with the direct information obtained by the public who supervise control over the vote counting process at every level of recapitulation.

\section{B. Feasibility of the Use of E-Recapitulation Technology}

The Head of the KPUD and the Head of Bawaslu of Pekalongan City Central Java Province stated that the purpose of the e-recap was as an effort to develop public confidence as well as to anticipate the future need which demands accurate counting with the higher level of electoral competition, within one party/between different parties in both 
the legislation election and the presidential election by utilizing IT technology that is fast, accountable and transparent.

Besides the use of e-recapitulation technology as an alternative access to exercise the right of the public to directly engage in the control of the vote counting process, the stakeholder (MoHA) could take advantage of the active public participation through e- recapitulation, so that in the future of the Monitoring Committee longer needed and the supervision can be conducted directly by the public, from the preparation process until the final stage of the election. Given Indonesia's heterogeneous topography / geography and time-consuming process of election counting, it is time for MoHA/ stakeholder to generally consider utilizing Information Technology (IT), to ensure that the process of voice counting in the future would be faster, transparent, accountable as well as providing a public mechanism to check all parties (election organizers).

In addition, also stated by one member of the KPUand one member of Bawaslu of Pekalongan City, Central Java Province that based on the current trend that the public was attached to their smart phones, then by using the camera/ android application as alternative media and synergized with the existing media in TPS e-recapitulation to facilitate the task of Panwas, Bawaslu as well as to obtain the data easily/accurately and for supervision and with the necessary election regulation in the form of tiered reports, the data obtained can be made into data/documents/source of information in the framework of direct supervision of TPS. The purpose of the e-recapitulation is to develop democracy and public trust with the principle of fast, accountable and transparent. The use of the e-recapitalization technology, besides improving election accountability, is also an alternative form of innovation leap in utilizing public participation directly from the preparatory process to the final stage.

From the above result, it can be stated that the e-recapitulation technology for the election results (in particular the USSD and the DMR technology) is feasible to be used on the upcoming 2019 election, based on its ability to maintain the integrity of the vote-counting results from the polling stations. However, the feasibility of using the technology must be followed by the effectiveness of the 2019 election. According to Triono (2017), there are at least 5 main aspects that need to be strengthened, namely: an aspirational and applicable election law as a legal umbrella as well as the design of the 2019 simultaneous election model, a capable and professional election organizer, the effectiveness of simultaneous election fund that is more pro-people, the readiness of political parties in a simultaneous election, and the need for political socialization and community participation. The implementation of effective election policy has a positive and significant influence on the performance of election organizers in providing a good quality election (Parhan, 2017).

All sources in this study (the KPUD Head and some of its members, and Bawaslu Pekalongan) stated that, in principle compared to the manual recapitulation process, the use e-recapitulation technology (especially the technology USSD and DMR) would: (1) speed up the of delivery of vote recapitulation results from each TPS to the public, (2) supportive of the public's right to be able to control the vote counting process, (3) provide better accuracy, (4) provide an authentic evidence of the vote count results in level of TPS, (5) provide better transparency, and (6) increase the accountability of the election (Setiawaty \& Vishnu, 2017).

\section{Factors Affecting the Implementation of E-Recapitulation Technology}

One of the KPUD members and one member of the Bawaslu Pekalongan City suggested a number of factors supporting the e-recapitulation technology of the vote count count if used in the upcoming 2019 general election, which are: (1) availability of Network Provider/Cellular operators with special channels with coverage in remote areas; and (2) Secure and Up to date Security system.

One of the KPUD members and one member of the Bawaslu Pekalongan City suggested a number of factors that inhibit the use of the e-recapitulation technology of the vote count if used in the upcoming 2019 general election, which are: (1) On the data input, the factors are: the weather, which might be affecting the provider's signal and the provider's coverage area on remote locations, the constraints of the field equipment with the operator for one TPS, the distance between the TPS is far; and potential hacking, (2) For the data transmission the factors are: the weather, which might be affecting the provider's signal and the provider's coverage area on remote locations (3) For TPS Data Receipt, the factor is: the availability of special operator in recording the acceptance of recapitulation data or in the KPPS itself, because the recapitulated data is in the KPPS, (4) the obstacles that are expected to appear in the process of recapitulation of the results are related to the comparison between the results of e-recap with the result with the KPU recap. (5) no apparent obstacle expected to arise in the publication of the recapitulation results, and (6) other barriers are generally that the smartphone use is still uncommon, an easy to use application is needed. In addition, the public disinterest towards the manual election process related to transparency and information disclosure also need to be addressed. 
From the explanation above, some of the main factors that can support the use of e-recapitulation technology if it is being employed in the upcoming 2019 election are: 1) an adequate and ubiquitous information technology infrastructure throughout Indonesia, (2) technology/e-recapitulation application that is easy to use, (3) human resources as the operators in the field understand and able to use the e-recapitulation technology, (4) computer hardware/smartphones that support the e-recapitulation technology (5) adequate network security that can counteract and anticipates attacks by crackers/hackers, (6) network providers/cellular operators with special channels which coverage reach the remote villages, and (7) the high demand from the public of the TPS vote count accuracy.

Thus, the feasibility of using e-recapitulation of vote counting in the upcoming 2019 election is also supported by several of key factors as identified above. However, there are still several factors that are expected to inhibit the use of e-recapitulation technology in the upcoming 2019 election, particularly the internet network. This is in line with Ardiyanti (2016), who stated that in order to adopt the electronic election system fully, there is a number of issues to be resolved, namely the lack of adequate legal, infrastructure and superstructure.

Prasetyo (2014) stated that the internet network in Indonesia lack behind (other countries), as such the very slow internet network might inhibit the use of e-recapitulation. Compared to other ASEAN countries, the average speed of Indonesian internet access is in the slowest three. The Household Download Index stated that the average speed of internet access in Indonesia is 4.65 Mbps. Indonesian internet speed is only better than Laos and the Philippines, with 4.09 Mbps and 3.41 Mbps. The Household Download Index is based on millions of test results in the last month conducted by Ookla, the provider of internet speed test site speedtest.net. The index compares and ranks the speed of download by internet users around the world. Based on that index, Indonesian internet speed is far behind Singapore or Thailand.

Compared to the world internet speed, Indonesian internet speed is also not encouraging. From 192 countries listed in the Household Download Index, Indonesia is in number 142, below African countries such as Zimbabwe and Kenya. Budi Setiawan, the Director General of Post and Informatics Ministry of Communication and IT acknowledged that in average Indonesian internet speed lacked behind other neighboring countries. To have a high-speed internet, a fixed broadband optical fiber network is needed. Unfortunately, the Indonesian internet network still relies on mobile broadband. The mobile network such as $3 \mathrm{G}$ network has a maximum speed of only 1 Mbps. The 3G network also not ubiquitous and mainly available in big cities (Prasetyo, 2014).

Different with the mobile network, the fixed broadband network can provide up to $50 \mathrm{Mbps}$. The users of the fiber optic network would certainly enjoy super-fast internet access. The problem is that $90 \%$ of Indonesian internet network is not using the fiber-optic network. As such, Indonesian internet would always be one of the slowest. The lack of fiber optic internet network is not without reason, the head of sub-directorate of Post, Telecommunication, and Informatics of the Ministry of National Development Plan, Mira Tayyiba stated that Indonesia's vast archipelagic geography inhibit deployment of fiber optic networks. As such, the internet network providers choose to deploy mobile networks instead of fiber optics. Vietnam could deploy the fiber optic network since all of their territories is in land. Taufik Hasan, member of the Professional Council and Association of Indonesian Telematics Society (Mastel) stated that Indonesian geography should not be the reason for the slow internet speed. The geography condition should be a challenge for the deployment of the internet network (Prasetyo, 2014).

Of course, the slow internet connection is not only due to the Indonesian geography. Chairman of Mastel, Mr. Setyanto P. Santosa stated that the slow internet speed was due to the bad internet network infrastructure. The Government never paid attention to the deployment of internet infrastructure. The Government had not allocated fund to deploy a good internet network. Samuel Abrijani Pangerapan, the Chairman of Association of Indonesian Internet Provider (APJII), agreed that the Indonesian internet infrastructure is minimal. Just like the road, the deployment of internet infrastructure is not as fast as the growth of the users. APJI survey mentioned, the number of internet users in Indonesia in 2013 reaches 71.18 million users. The internet user penetration reached $28 / 8 \%$ of the total population. As such, Setyanto stated that the deployment of broadband networks should be a priority. The government currently relied on the network providers to deploy the internet network. The government should start to build the broadband network in Indonesia. Since it is the government duty to build infrastructure (Prasetyo, 2014).

The Government should start to treat the broadband network as one of the economic infrastructures, such as roads and harbors. If necessary, the future government should place the MoCIT under the Coordination Ministry for Economics. If the MoCIT still under the Coordination Ministry of Politics, Law, and Security, MoCIT would 
only deal with internet security and pornography. MoCIT would not think about the economic aspects. Mira stated that the data infrastructure in Indonesia does need to be taken care of. That is the reason, since 2012, the government started to build the Indonesian Broadband Roadmap. Last May, the government completed the 2014-2019 Indonesian Broadband Plan. Currently, the government is preparing a presidential regulation for the legal base of the document.

The Indonesian Institute of Sciences (LIPI) conducted a public survey on their view on technology and science (IPTEK). Based on the survey, there were three main issues, First, a great discovery, second, it contributed to a better life and three, it changed fast. Of the three, the great discovery was the most widely viewed by the public (76 percent). Unfortunately, most of the public does not understand the IPTEK issues in Indonesia. Almost 54 percent of the respondents do not have a good grasp on the IPTEK issues.

Furthermore, in relation to the quality of election organizers, the General Elections Commission (KPU) complains about the low quality of Human Resources (HR) of election organizers in regions that result in delays in the determination of legislative election results in some areas. The workload of election officials in the regions is quite heavy, but the compensation they receive is low. The officers could not perform their duties to the maximum effort. This resulted in them to work unprofessionally.

Although in term of the technology/device the e-recapitulation technology of election recapitulation (in particular the USSD and DMR) is feasible to be used in the upcoming 2019 elections, it is expected to encounter various obstacles as identified above. Therefore, there should be policy to anticipate the obstacles that are expected to emerge and solve the problems in the use of the recapitulation technology in the upcoming 2019 election.

\section{Policy to Anticipate Obstacles in the Use of E-Recapitulation Technology}

According to one of the members of the KPUD and one member of Bawaslu Pekalongan City, to anticipate the obstacles: (1) MoHA should establish early communication with the Central KPU to provide an opportunity/at a minimum to require the use of e-recapitulation technology in 2019 general elections to further improve the quality of democracy in Indonesia, (2) Government through MoHA and KPU need to make clear and detail guidelines related to the electronic vote counting process, including details of the PPS Supervisor/KPPS duties as well as SOP for the use of e-recapitulation technology, (3) the Regional Government and the KPUD should provide training to the personnel or Ad hoc election committee member to increase their understanding of the IT technology being used, (4) Regional Governments, KPUDs and other relevant agencies should strive for a fairly good internet network throughout the region as well as application of e-recap technology that iscompatible with the receiving equipment, (5) KPUD must prepare the device in anticipation of possible attacks from crackers/ hackers that would interfere with the process of electronic vote count, (6)Regional Governments, KPUD, regional Bawaslu, BPPT and the Office of Communications and Informatics should socialize the e-recapitulation technology prior to its use, especially to community leaders and traditional leaders who have not yet understood the transparency and disclosure aspects. (7) Before e-recapitulation technology is used, MoHA, KPU, Bawaslu, Pemda, and KPUDs should continue to conduct comprehensive technical and sociological assessments in their use plans, including the review of their implementation from the standpoint of applicable law and regulations, (8) the KPUD should prepare sufficient budgets to implement the e-recapitulation technology throughout Indonesia, including preparing adequate human resources and infrastructure (such as internet network) in remote TPS throughout Indonesia, and (9) Bad internet connection is not solely due to the Indonesian geography. Slow internet connection is due to a bad internet network. As such, the Government should pay more attention to the deployment of internet infrastructure. The Government has to allocate adequate fund to deploy a good internet network. Since one of the success factors for the e-recapitulation technology is the ubiquitous internet network in the villages throughout Indonesia.

\section{ConClusion}

The test results of the use of e-recapitulation technology in the 2014 legislative elections in Pekalongan City with the USSD (Unstructured Supplementary Service Data) technology and the DMR (Digital Mark Reader) technology in 564 TPS is much better than the manual recapitulation of vote results, the e-recapitulation technology was able to provide faster and more accurate data transmission of election results.

Basically, the e-recapitulation technology for the election results (in particular the USSD and DMR) is feasible to be used on the upcoming 2019 election, based on its ability to maintain the integrity of the vote-counting results from the polling stations. Although in term of the technology/device the e-recapitulation technology 
of election recapitulation (in particular the USSD and DMR) is feasible to be used in the upcoming 2019 elections, however, it is expected to encounter various obstacles as identified above.

Therefore, there should be policy to anticipate the obstacles that are expected to emerge and solve the problems in the use of the recapitulation technology in the upcoming 2019 election.

\section{ACKNOWLEDGEMENT}

The author would like to thank the Pusat Litbang Politik, PUM and Otda BPP of MoHA who has assisted this study.

\section{REFERENCES}

Andrari, G. (2016). Teknologi Perhitungan Suara dalam Pemilu Serentak 2019. In Fokus Grup Aktual Pusat Litbang Otda, Politik, dan PUM BPP Kemendagri. Jakarta.

Ardiyanti, H. (2016, August). Uji Coba E-Verifikasi dan Masa Depan Pemilu Elektronik 2019. Majalah Info Singkat Pemerintahan Dalam Negeri, VIII(15), 17-20. Retrieved from https:// berkas.dpr.go.id/puslit/files/info_singkat/Info Singkat-VIII-15-I-P3DI-Agustus-2016-33.pdf

Bachtiar, F. R. (2014). Pemilu Indonesia: Kiblat Negara Demokrasi dari Berbagai Refresentasi. Jurnal Politik Profetik, 3(1). http://doi. org/10.24252/jpp.v2i1.817

Fuadi, A. B. (2015). Tinjauan Yuridis Sistem Electronic Voting dalam Penyelenggaraan Pemilihan Umum di Indonesia. Sunan Kalijaga State Islamic University. Retrieved from http:// digilib.uin-suka.ac.id/19032/

Jumansyah. (2015). Perbandingan Sistem Rekapitulasi Penghitungan Suara pada Pemilihan Umum Legislatif Tahun 2009 dan Tahun 2014 di Kota Samarinda (Studi Kasus Sistem Rekapitulasi Penghitungan Suara Tingkat Kecamatan dan Tingkat Kelurahan). eJournal Ilmu Pemerintahan, 3(4), 1554-1566. Retrieved from http://ejournal.ip.fisip-unmul. ac.id/site/?p=1691

Lembaga Penelitian Pendidikan Penerangan Ekonomi dan Sosial (LP3ES). (2014). Laporan Evaluasi Pemilu 2014 di 3 (Tiga) Provinsi: Sumatera Utara, Jawa Tengah dan Papua. Laporan Evaluasi Pemilu 2014. Jakarta: Lembaga Penelitian Pendidikan Penerangan Ekonomi dan Sosial (LP3ES).
Miharja, B. P., Suprapto, F., Puspitarani, Y., \& Sukenda. (2014). Aplikasi Pengelolaan Data Voting pada Pemilihan Umum Kepala Daerah dengan Fingerprint. E-Journal Informatics Final Year Project, 1(3). Retrieved from http://ejournal. widyatama.ac.id/index.php/if_utama/article/ view/91

Parhan. (2017). Pengaruh Pelaksanaan Kebijakan Pemilu dan Manajemen Pemilu terhadap Kinerja Penyelenggara Pemilu untuk Mewujudkan Kualitas Pemilu. Jurnal Publik, 11(2), 205-218. Retrieved from https:// journal.uniga.ac.id/index.php/JPB/article/ view/174

Prasetya, W. (1997). Sistem Penghitungan Suara Pemilu Multi Sekuriti. Depok, Indonesia. Retrieved from http://www.staff.science. uu.nl/ prase101/mypapers/protokol_pemilu. pdf

Prasetyo, H. (2014, August 13). Jaringan Internet di Indonesia Jauh Tertinggal. (I. Alexander, Ed.), Kontan Mingguan. Retrieved from https:// industri.kontan.co.id/news/jaringan-internetdi-indonesia-jauh-tertinggal

Purwati, N. (2015). Perancangan Sistem E-Voting untuk Pemilihan Kepala Daerah (Pilkada). Jurnal Bianglala Informatika, 3(1), 18-27. Retrieved from https://ejournal.bsi.ac.id/ ejurnal/index.php/Bianglala/article / view $/ 573$

Setiawaty, D., \& Vishnu, S. (2017). Rekapitulasi Elektronik: Langkah Strategis dalam Pengembangan Teknologi Pemilu di Indonesia. Jurnal Pemilu \& Demokrasi, (9). Retrieved from http://perludem.org/2017/01/27/ jurnal-9-kodifkasi-undang-undang-pemilupembaruan-hukum-pemilu-menuju-pemiluserentak-nasional-dan-serentak-daerah/

Shalahuddin, M. (2009). Pembuatan Model E-Voting Berbasis Web (Studi Kasus Pemilu Legislatif dan Presiden Indonesia). Bandung Institute of Technology (ITB). Retrieved from http://www. digilib.itb.ac.id/files/disk1/690/jbptitbppgdl-muhammadsh-34484-1-2009ts-r.pdf

Surbakti, R., Supriyanto, D., \& Santoso, T. (2013). Perekayasaan Sistem Pemilu untuk Pembangunan Tata Politik Demokratis. Jakarta: Kemitraan.

Triono. (2017). Menakar Efektivitas Pemilu Serentak 2019. Jurnal Wacana Politik, 2(2), 156-164. http://doi.org/10.24198/jwp.v2i2.14205 